\section{Knowledge transfer at the basis of the competitiveness: A critical review of the main policies}

UTE. Revista de Ciències de l'Educació

Monogràfic 2018. Pàg. 69-81

ISSN 1135-1438. EISSN 2385-4731

http://revistes.publicacionsurv.cat/index.php/ute

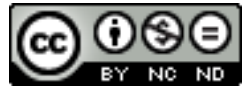

DOI: https://doi.org/10.17345/ute.2017.3.1940

\author{
Alice Civera, Michele Meoli y Stefano Paleari \\ Afiliació Department of Management, Information and Production Engineering, \\ University of Bergamo, Italy \\ CCSE -HERe, CisAlpino Institute for Comparative Studies in Europe, Higher Education Research \\ group \\ Rebut: 08/09/2017 Acceptat: 13/10/2017
}

\begin{abstract}
Several are the concomitant factors enabling the development of the knowledge transfer, first among all the awareness that university knowledge is at the basis of innovation and business productivity, generating relevant competitive advantages. Public policies have focused on fostering kind of mechanisms, both at national and European level. However, the knowledge transfer is a complex process, involving several actors and different objectives, often conflicting. Our review of the literature reveals that the obstacles to an effective and efficient knowledge transfer are numerous and of various nature, ranging from incentive system at individual level to process managing at institutional level as well as at national and European level. We focus on the tree main knowledge transfer mechanisms, namely licensing, patenting and start-up companies. Extant studies show that steps have been taken but there is still long way to go. Suggestions for policy makers and management are provided, and implications are discussed in the concluding section.
\end{abstract}

Keywords: Knowledge transfer, competition, university policy.

\title{
Resumen
}

Varios son los factores concomitantes que permiten el desarrollo de la transferencia de conocimiento, en primer lugar entre toda la conciencia de que el conocimiento universitario es la base de la innovación y la productividad empresarial, generando ventajas competitivas relevantes. Las políticas públicas se han centrado en fomentar tipos de mecanismos, tanto a nivel nacional como europeo. Sin embargo, la transferencia de conocimiento es un proceso complejo que involucra a varios actores y diferentes objetivos, a menudo en conflicto. Nuestra revisión de la literatura revela que los obstáculos para una transferencia de conocimiento eficaz y eficiente son numerosos y de diversa naturaleza, desde el sistema de incentivos a nivel individual hasta la gestión de procesos a nivel institucional, así como a nivel nacional y europeo. Nos enfocamos en los principales mecanismos de transferencia de conocimientos, principalmente licencias, patentes y empresas de nueva creación. Los estudios existentes muestran que se han tomado medidas, pero aún queda mucho camino por recorrer. Se brindan sugerencias para los responsables de las políticas y la administración, y las implicaciones se discuten en la sección final.

Palabras clave: Transferencia de conocimiento, competencia, política universitaria. 


\section{Introduction}

Knowledge is considered the basis for national competitive advantage within the international marketplace (Ozga and Jones, 2006). Research produces knowledge and has become central to economic growth nowadays, in what is called the Knowledge Economy (Peters, 2009; Kenway et al., 2004). The central role of knowledge is confirmed even by the World Bank, in its publication Constructing knowledge economies: Continuous, market-driven innovation is the key to competitiveness, and thus to economic growth, in the knowledge economy. This requires not only a strong science and technology base, but, just as importantly, the capacity to link fundamental and applied research, to convert the results of that research to new products, services processes or materials and to bring these innovations quickly to the market (World Bank, 2002, p. 21).

They have proved to be enabling factors the increased demand for higher education, internationalization of education and research, competition deriving from the proliferation of alternative knowledge producers, the interdisciplinary reorganization of knowledge, and the emergence of new expectations (Commission 2003, pp. 6-9; see also Bilbao-Osorio and Rodriguez-Pose, 2004). Again, the emergence of "new" technology driven industries, such as Biotechnology, Information and Communication Technology and Nanotechnology, where scientific knowledge is particularly relevant; the increasing reliance on universities as policy instruments to drive local development processes, and key actors in regional innovation systems (Florida, 2002).

Consequently, both at international and national level policymakers promote a coherent set of policy themes and processes seeking to ensure competitive advantage through the commercial exploitation and application of knowledge (Ball, 1998). This has resulted in bringing knowledge production into close relationship with economic policy and universities and their research became significant players in this policy frame. That, however, has not always been the case as a considerable literature demonstrates. The transfer from social science research to policy is indeed a complex process, since academics and practitioners have fundamentally different frames of reference (see, for example, Shrivastava and Mitroff, 1984); different goals, different systems in which they operate, different variables they attempt to manipulate (Johns, 1993; Powell and Owen-Smith, 1998; Thomas and Tymon, 1982). Therefore, they belong to separate communities with very different values and ideologies (Beyer and Trice, 1982).

Changes in economic and political conditions are estimated to be the causal factor of such shift. The intensification of global competition put organizations under pressure to become more effective (Abrahamson and Fairchild, 1999; Micklethwait and Wooldridge, 1996; Pfeffer and Sutton, 2000). Practitioners reconsidered the contribution of academic researchers that even more often fill the lack of research staff within organizations due to the required cuts (Cohen et al., 1998; Powell and Owen-Smith, 1998). In practice, public policies are encouraging collaborations between industry and academy by providing tax breaks for corporate funding of university research and developing funding programs that require industry-university collaboration as a condition for funding (Cohen et al., 1998). As consequence, policy makers have increasingly become involved in academia, which has led to increased donations to higher education, expanded participation in academic advisory boards, raised recruitment of academic researchers by private industry, participation in university-industry research consortia (UIRCs), and location of corporate research and development activities near major universities (e.g., Burack, 1999; Slaughter and Leslie, 1997).

From the academics' point of view, universities are even more dependent on private sector for financing teaching and research activities, since public funding for higher education as a percent of total revenues and federal research support per academic researcher have both been declining 
for over two decades (Cohen et al., 1988). Among the causes, it is included the development of new public management views of government action towards reduced and more efficient government intervention in the economy and the introduction of the EURO and the high spending on health and pensions throughout Europe. Furthermore, competition increased because of the emergence of higher education competitors such as corporate and for-profit universities for teaching (Meister, 1998; Mowday, 1997) and consulting companies for research (e.g., Abrahamson, 1996; Micklethwait and Wooldridge, 1996). In response to this kind of new pressures, public policy has increased the incentives for universities, both for individuals and faculty (Powell and Owen-Smith, 1998). The commonly known Bayh-Dole Act is a prime example, which is a Patent and Trade Amendments from 1980 to allow universities to retain the property rights to scientific invention (Powell and Owen-Smith, 1998; Slaughter and Leslie, 1997). Likewise, universities started to look for alternative source of financing in the form of direct research funding from organizations such as research councils and not-for-profit organizations (see the role of the Wellcome Trust in the UK and Bank Foundations in Italy), and from the so-called third stream activities. Such funds have a particular importance for UK's universities but even for EU countries, as it is testified by the introduction of the direct research funding in Italy-Fondo Investimenti per la Ricerca di Base-and the creation of the Agence Nationale de la Recherche in France in the middle of 2000.

To sum up, the affirmation of university knowledge as one of the drivers of innovation and business productivity, generating competitive advantages (Cohen and Noll, 1994; Nonaka and Takeuchi, 1995) as well of the diffusion as the knowledge transfer process have several causes. In the next section we provide a panoramic view of the main polices in higher education sector with a particular emphasis on the Bologna Process and the Lisbon Agenda reforms. Sections 3 and 4 are more focused on the knowledge transfer, discussing respectively the process and the different types of mechanisms. Section 5 concludes and underlies policy implications at national as well as European level.

\section{A panoramic view of the policies in Higher Education sector}

The current situation of the European higher education sector can be attributed to three different phases of reforms (Maassen and Stensaker, 2011).

The first phase corresponds exactly to the expansion in the number of higher education students since 1960 s to $1990 \mathrm{~s}$. It had repercussions on public spending on higher education and led universities to introduce a self-regulatory mode of governance (Goedegebuure et al., 1994) to address efficiently society's diverse needs. By stimulating competition and by fostering institutional autonomy, universities were driven to be more oriented towards their consumers' demands. The second phase can be interpreted as the direct consequence of the first one. It was characterized by reforms involving output funding and multiyear agreements or contracts with individual higher education institutions. From 1990s indeed the development of "market-oriented state" resulted in a renovate interest in state influence in higher education (Paradeise et al., 2009).

At the same time, new types of intermediate bodies and agencies arose (Hood et al, 2004), creating hybrid steering approaches with multi-actor, multi-level governance frameworks emerging (Gornitzka and Maassen, 2000). The final phase started from the introduction at European level of two new joint reform and policy, namely the Bologna Declaration in 1999, which aimed at creating a European Higher Education Area by 2010, and the general Lisbon Strategy in 2000, which intended to make Europe the world's most competitive and dynamic knowledgebased economy by 2010 (Stensaker et al., 2006). 
The Bologna Declaration had as its object creating a European Higher Education Area by converging national higher education structures, which facilitates student and stuff mobility and reinforce the competitiveness of European higher education all over the world. The first step has been implementing an accreditation system of some kind, which guaranteed the quality assurance by establishing a minimum threshold level (Schwarz and Westerheijden, 2004). The development of new standards and guidelines was the following step and it was achieved thanks to the European Standards and Guidelines for quality assurance as well as to the ministerial Bologna meeting in London in 2007, which set a new Register for quality assurance agencies. However, different were the priorities for policy makers. The research policy was instead focused on identifying those institutions, groups and individual researchers that stood out from the rest (Aghion et al., 2010). At European level the establishment of the European Research Council and the set-up of a European Institute of Innovation and Technology (EIT) are proof of it. Moreover, there are many examples also at national level, ranging from Denmark where since 2004 political initiatives to create top/elite institutions able to compete with top universities globally, to Germany and other European countries.

Compared to the ambitious but delimited aspirations of the Bologna process, the Lisbon Agenda was guided by the development in the next 15-20 years of the university-based research and innovation (Commission, 2003; 2004; 2005; 2006). At the centre of the debate building a single research market to ease mobility and brain drain, as well as to spread innovation which has an undisputed place as a core element in competitiveness (Larédo, 2003). The Lisbon Summit did at least two things (Gornitzka, 2007). The role of innovation in terms of research and development is thus reasserted as crucial for economic competitiveness and growth, as well as the key contribution of education in the labor market as well as in the society as cohesion factor.

Since education, research and innovation jointly are seen as vital in the creation of a "Europe of Knowledge" (Commission, 2005), knowledge transfer has become a strategic issue as a source of funding for university research and (rightly or wrongly) as a policy tool for economic development.

\section{The knowledge transfer process}

According to (Siegel et al., 2007), the main phases of the knowledge transfer process are (i) the disclosure of inventions and ownership of IP, (ii) bringing university intellectual property to the market and (iii) the valuation of inventions.

Invention disclosure represents the most critical input in the knowledge transfer process. To formalise this kind of activity, in US it was introduced in 1980s the Bayh-Dole Act, according to which academics are forced to disclose their innovation to their university if they receive a federal research grant. An increasing number of European countries (e.g. Denmark and Germany) introduced Bayh-Dole Act -like regulation, giving up the intellectual property rights to the university. However, this rule is rarely enforced so many faculty members are not disclosing their inventions to their university (Siegel et al., 2004; Thursby et al., 2001). To elicit disclosures, universities need proper incentive schemes specifying an adequate share for the inventors in royalties or equity, as suggested by several studies (Macho-Stadler et al., 1996; Jensen and Thursby, 2001; Lach and Schankerman, 2004; Link and Siegel, 2005).

Once the universities achieved the invention disclosure, the Technology Transfer Office - the intellectual property owner in many countries - consulting a committee of faculty experts determines if such invention should be patented. To make such decision the office evaluates the commercial potential of the innovation in base of the interest expressed by the industry. If the companies/entrepreneurs show scarce interest, the high cost of filing and protecting patents does 
not warrant filing a patent. Otherwise, the university try to enter in the market by contacting firms that can potentially license the technology or entrepreneurs who are capable of launching a startup firm based on the technology. Researchers might be directly involved in the licensing agreement as technical consultants or as entrepreneurs in a university spin-off. Jensen and Thursby (2001) found evidence that the probability of success in licensing and commercializing a university-based technology is enhanced by the involvement of the faculty members. Moreover, royalties are found to be the most decisive incentive, either at the beginning or at the end of the process. Notwithstanding, university spin-offs are more profitable than licensing agreements and that is why an extensive literature focused on such kind of companies. Researchers need to be strongly involved in this activity, even from the financial point of view in order to have the appropriate level of incentive to participate. Macho-Stadler et al. (2006) demonstrated that part of the founder shares has to be allocated to the academics to achieve the optimal agreement among all the actors involved, namely the university, individual researchers and financiers.

Considering patents and licenses in promotions and tenure negotiations, and allowing faculty members a larger share of licensing or equity revenues cannot however be enough to reward faculty for their participation in knowledge transfer activities. Greater pecuniary rewards to university inventors does not necessarily imply a higher likelihood of creating marketable outputs (Friedman and Silberman, 2003).

Higher education institutions address such issue by defining university policies for distributing income generated by licensing and sponsored research (Siegel et al., 2007) as well as for establishing an appropriate royalty regime also for academic spin-off activity (Di Gregorio and Shane, 2003). In the case of university-based companies, the relevance of effective royalty regimes is flanked by the increasingly strategic role of Technology Transfer Office in commercializing intellectual property. To make things even more complicated, the increasing use of Technology Transfer Offices does not necessarily bring an acceleration of the knowledge transfer process (Siegel and Phan, 2005).

Even in presence of the perfect incentive schemes, not every invention can be licensed and/or patented due a problem of asymmetric information between industry and academies. An external company can barely evaluate the quality of the invention a priori while university can hardly estimate the effective commercial profitability of their inventions. A potential solution to this information asymmetry is suggested by Macho-Stadler et al. (2007) and depends on the reputation of the university Technology Transfer Office. This should indeed select only promising project with the aim of building quality reputation and according to the signaling theory convincing the buyers of the quality of the products. This can be guarantee exclusively by a critical size of this Technology Transfer Office.

\section{Types of knowledge transfer mechanisms}

Knowledge transfer is a broad concept and involves many activities, ranging from collaborative research projects involving universities and companies (e.g. research contracts), intellectual property rights (IPR) and spin-offs, labor and student mobility, consultancy, etc., as well as "softer" forms of knowledge transfer, such as attendance at conferences and creation of electronic networks (Geuna and Muscio, 2009).

The vast majority of the studies investigating the patterns of diffusion of inventions are US based. Nonetheless, European researchers are increasingly adopting European university-based data in 
their papers to complement this literature. Most of the empirical studies focused on three specific mechanisms: (i) licensing, (ii) patenting, (iii) start-up activity (Geuna and Muscio, 2009).

\subsection{Licensing and patenting}

The Bayh-Dole Act is intended as one of the most significant driver of the licensing and patenting activity. Thursby and Thursby (2002) confirmed it by demonstrating that the diffusion of such kind of knowledge transfer activity is not linked to changes in the direction of faculty research but rather to the increasingly proclivity of administrators to engage in commercializing university research - which is nothing more than an intended effect of the Bayh-Dole Act.

There is however not shortage of criticism around this regulation. Valentin and Jensen (2006) provided evidence that since January 2000, when the law came into force in Denmark, the Danish academic inventors involved in patents owned by dedicated biotechnology firms have dramatically decreased. The authors ascribed this considerable reduction to this new regulation, which forced the inventor to cede to the university the right of ownership of a patent leading to discourage collaboration in early stage research where identification of shares or rights is extremely difficult. As discussed above, in many cases faculty members do not disclose their inventions to their university to circumvent this law (Markman et al., 2008; Thursby et al., 2009). Several are the scholars who tried to provide policy suggestions in order to overcome a situation that threatens to be stagnant. Link and Siegel (2005) prompted the royalty distribution formula, a particular organizational practice to allocate to a faculty member who develops the new technology the fraction of revenue from a licensing transaction. The efficiency in knowledge transfer activities results to be directly proportional to the percentage of royalty payments to researchers. Likewise, Friedman and Silberman (2003) and Lach and Schankerman (2004) confirmed the relevance of this kind of incentive. Again, Jensen et al. (2003) argued that adequate incentives stimulate the researchers to put greater effort in knowledge-based activities and draw attention of the most productive researchers. Indeed, high-quality faculty augments the rate of invention disclosure in the early stages but is inversely related to share of licensing income allocated to inventors.

Other authors focused instead on the technology transfer and the performances of the Technology Transfer Office. The quality of transacted inventions is positively affected by bonuses raise licensing income, which are in turn jeopardized by specifying local development objectives or imposing government constraints on licensing practices of Technology Transfer Offices (Belenzon and Schankerman, 2007). Moreover, complementing the US-based study of Link and Siegel (2005), Debackere and Veugelers (2005) beyond confirming that a higher percentage of royalty payments to faculty members tend enhances the effectiveness in technology transfer, they defined as critical success factor a decentralized management style of the Technology Transfer Office, which thereby results much more sensitive to the needs of its stakeholders.

\subsection{Start-ups}

Similar to what we presented in the previous section, in this one we report selected study about policies fostering start-up activity. Degroof and Roberts (2004) and Roberts and Malonet (1996) selected two dimensions within academic spin-offs policies, namely the level of selectivity and the level of support of academic institutions. However, since such a comprehensive policy is not feasible, they suggested to formulate comparable policies at a higher level of aggregation than the institutional one. Lockett and Wright (2005) provided additional evidences on the topic, identifying as drivers of start-up formation the university expenditure on intellectual property 
protection, the business development capabilities of the Technology Transfer Offices, and the royalty distribution formula.

Frankling et al. (2001) recommended instead of focusing on internal resources of university to overcome the typical cultural and informal barriers encouraging external surrogate entrepreneurs to assume a leadership role within the spin-off company. That is a somehow innovative solution basing on the idea of a hybrid model involving academic and surrogate entrepreneurs. More traditional is the contribution of other studies underlying once again the relevance of incentives. Equity ownership is according to Lockett et al. (2003) and Di Gregorio and Shane (2003) the mean enabler factor of the start-up formation, while the latter identified the royalty distribution formula as an inhibitor of such kind of activity. Results are confirmed also by Markman et al. (2005).

\section{Conclusions and policy implications}

The knowledge transfer topic is becoming even more crucial for policy makers since it is well known that Europe underperforms in knowledge transfer activities compared to the US. To fill the gap, the European Commission made the first step in 2007 by launching a policy program named Putting Knowledge into Practice.

Several are the areas of intervention suggested by the literature in order to create a Pan-European market for industry-science transfers that can compete with the American one (Siegel et al., 2007). First, incentivizing researchers to take part in knowledge transfers aligning ownership regimes and setting-up flagship programs, which may represent a reference model for industry-science interaction mechanisms. Second, professionalizing knowledge transfer personnel and creating a framework for mutual recognition of qualifications and an EU-wide accreditation scheme. Third, pooling resources to a sole industry sector or a sole knowledge-transfer activity in order to create mass size and an efficient scale of Technology Transfer Offices. Some countries have moved in this direction and the European Community provides the Innovation Relay Centres network as support service activity. Fourth, creating bridges between cultural differences existing between academies and industry. An effective way would be to enhance mobility of staff between these two realities. The Framework Program Marie Curie Industry-Academia Strategic Partnership promoted by the European Commission has properly this scope. Similarly at national level, the new research, development, and innovation (RDI) State Aid Regulations permits to deploy temporarily high qualifies staff from research institutions to the industry. Fifth, compensating the lack of private investments in knowledge transfer with further government funding. The European Commission provides funds directly to the regional or local level according to the Community Framework for State Aid for Research, Development and Innovation and co-finances some knowledge transfer activities identified by the specific European Structural and Cohesion Funds programs. Lastly, benchmarking commercial activities of scientific organizations by adopting standardized metrics across the Europe in order to compare its own output with the US ones. Several attempts have been conducted both at European ad global level - namely AUTM, OECD, Association of European Science and Technology Transfer Professionals (ASTP), and Proton without however achieving the adequate level of detail to ensure a satisfying benchmarking.

Therefore, the key to success seems to be creating a policy framework for improving knowledge transfer, which complements national and regional policy initiatives. The European Community has started to encourage the cooperation between regional and national policies through the Open Method of Coordination initiative, as well as the ERAnet and PRO INNO Europe. However, the objective is far from being achieved and there is no shortage of problems, especially concerning the potential implications that such policies may have on universities. The establishment of new national and supranational accreditation schemes is completely in contrast 
with the concept of renewal and creativity at the basis of the innovation area. Furthermore, a too much pronounced attention toward research at the expense of the teaching activity may be translated in a "market-failures" as academic standards could be replaced by a race for prestige (Dill, 2007). Vice versa, since the majority of incomes for universities comes from undergraduate education, research activity can be subordinated to the teaching one and research concentration cannot be feasible. And this may damage those higher education institutions which compete for reputation counting on the visibility in the global rankings (van Vught, 2008). Moreover, concentration of resources for research activity may penalize the development of innovation networks because the strategic ability of a given university of generating external links results undermined (Geiger, 2004; Geuna and Martin, 2003).

There are dissenting opinions about the relationship between research funding and innovation outputs. Whereas Gulbrandsen and Smeby (2005) provided evidences that industry funding is quite positively related to research performances such as applied research, external collaboration and networks, Marksman et al. (2004) shows an inverse relationship between paying royalties to faculty and entrepreneurial attitudes, which testify that financial aspects play little or even no role in motivating faculty to embark on invention-producing research projects.

Several are therefore the challenges to be addressed by university administrators, industry, and policy-makers (e.g. regional or state authorities) in Europe (Wright, 2007).

At university level, institutions should adopt a strategic approach to the commercialization of intellectual property (Siegel et al., 2007). This means setting institutional goals, priorities and consequent resource allocation - not an easy task because of the institutional heterogeneity. From a more practical perspective, academies should choose the stage of development of the technology to license as well as the mode of commercializing, i.e. licensing, start-ups, sponsored research, or consulting, and other mechanisms of technology transfer that are focused more directly on stimulating economic and regional development, such as incubators and science parks. Furthermore, in accordance to regional stakeholders, university management should select the technology field of emphasis, between and within the life sciences and physical sciences (Wright et al., 2004). In case of lack of critical mass of Technology Transfer Office within single universities, there may need to be development of collaborations at regional level. Again, universities also need to formulate intellectual property and patent strategies, calling for a greater transparency from the Technology Transfer Office, which have to assure that the intellectual property is protected before being commercialized. The ownership of intellectual problems has already mentioned is a big deal which can be solved by adapting promotion and remuneration systems for academics both at systemic and institutional level. An adequate intellectual property and patent strategy allows to decide what technology is proprietary to the university, which is licensed on an exclusive base, and which parts are licensed on a non-exclusive basis. 


\section{References}

Abrahamson, E. (1996). Management fashion. Academy of Management Review, 21(1), 254-285.

Abrahamson, E., \& Fairchild, G. (1999). Management fashion: Lifecycles, triggers, and collective learning processes. Administrative Science Quarterly, 44(4), 708-740.

Aghion, P., Dewatripont, M., Hoxby, C., Mas-Colell, A., \& Sapir, A. (2010). The governance and performance of universities: evidence from Europe and the US. Economic Policy, 25(61), 7-59.

Ball, S. J. (1998). Big policies/small world: An introduction to international perspectives in education policy. Comparative Education, 34(2), 119-130.

Belenzon, N., \& Schankerman, M. (2007). Harnessing Success: Determinants of University Technology Licensing Performance. CEPR Discussion Paper.

Beyer, J. M., \& Trice, H. M. (1982). The utilization process: A conceptual framework and synthesis of empirical findings. Administrative Science Quarterly, 591-622.

Bilbao-Osorio, B., \& Rodriguez-Pose, A. (2004). From R\&D innovation to economic growth in the EU. Growth and Change, 35(4), 434-455.

Burack, E.H. (1999). Bridging research to corporate application. In L. Larwood \& U.E. In Gattiker (Eds.), Impact analysis (pp. 17-46). Mahwah, NJ: Lawrence Erlbaum Associates.

Cohen, L. R., \& Noll, R. G. (1994). Privatizing public research. Scientific American, 271(3), 72-77.

Cohen, W., Florida, R., Randazzese, L., \& Walsh, J. (1998). Industry and the academy: Uneasy partners in the cause of technological advance. In R.G. Noll (Eds.), Challenges to research universities (pp. 171-199). Washington D.C.: Brookings Institution Press.

Commission. (2003). The role of the universities in the Europe of knowledge. Brussels: COM (2003) 58 final.

Commission. (2004). The Europe of knowledge 2020: A vision for university-based research and innovation. Liège, Belgium 25-28 April 2004, Conference Proceedings edited by G. Blythe, B. Hasewend\&B. Laget.

Commission. (2005). Mobilising the brainpower of Europe: Enabling universities to make their full contribution to the Lisbon strategy. Brussels: $\operatorname{COM(2005)} 152$ final.

Commission. (2006). Delivering on the modernization agenda for universities: Education, research and innovation. Brussels: $\operatorname{COM(2006)} 208$ final.

Cooke, P., Uranga, M. G., \& Etxebarria, G. (1998). Regional systems of innovation: an evolutionary perspective. Environment and planning A, 30(9), 1563-1584.

Debackere, K., \& Veugelers, R. (2005). The role of academic technology transfer organizations in improving industry science links. Research policy, 34(3), 321-342.

Degroof, J. J., \& Roberts, E. B. (2004). Overcoming weak entrepreneurial infrastructures for academic spin-off ventures. The Journal of Technology Transfer, 29(3), 327-352. 
Di Gregorio, D., \& Shane, S. (2003). Why do some universities generate more start-ups than others?. Research policy, 32(2), 209-227.

Dill, D. D. (2007). Will market competition assure academic quality? In D. F. Westerheijden, B. Stensaker, \& M. J. Rosa (Eds.), Quality assurance in higher education. Dordrecht: Springer.

Florida, R. (2002). The economic geography of talent. Annals of the Association of American geographers, 92(4), 743-755.

Franklin, S. J., Wright, M., \& Lockett, A. (2001). Academic and surrogate entrepreneurs in university spin-out companies. The Journal of Technology Transfer, 26(1), 127-141.

Friedman, J., \& Silberman, J. (2003). University technology transfer: do incentives, management, and location matter?. The Journal of Technology Transfer, 28(1), 17-30.

Geiger, R. (2004). Knowledge \& money: Research universities and the paradox of the marketplace. Stanford: Stanford University Press.

Geuna, A., \& Martin, B. (2003). University research evaluation and funding: An international comparison. Minerva, 41(4), 227-304.

Geuna, A., \& Muscio, A. (2009). The governance of university knowledge transfer: A critical review of the literature. Minerva, 47(1), 93-114.

Goedegebuure, L., Kaiser, F., Maassen, P., \& De Weert, E. (1994). Higher education policy in international perspective: An overview. En F. Kaiser, P. Maassen, L. Meek, F. van Vught, E. de Weert y L. Goedegebuure (Eds.), Higher education policy: An international comparative perspective (pp. 1-12). Oford: Pergamon Press.

Gornitzka, Å. (2007). The Lisbon process: A supranational policy perspective. In P. Maassen \& J. P. Olsen (Eds.), University dynamics and European integration (pp. 155-178). Dordrecht: Springer.

Gornitzka, Å., \& Maassen, P. (2000). Hybrid steering approaches with respect to European higher education. Higher Education Policy, 13(3), 267-285.

Hood, C., James, O., Peters, B. G., \& Scott, C. (2004). Controlling Modern Government. Variety, commonality and change. Cheltenham: Edward Elgar.

Jensen, R. A., Thursby, J. G., \& Thursby, M. C. (2003). Disclosure and licensing of University inventions:'The best we can do with the $s^{\star *}$ t we get to work with'. International Journal of Industrial Organization, 21(9), 1271-1300.

Jensen, R., \& Thursby, M.C. (2001). Proofs and Prototypes for Sale: The Licensing of University Inventions. American Economic Review, 91(1), 240-59.

Johns, G. (1993). Constraints on the adoption of psychology-based personnel practices: lessons from organizational innovation. Personnel Psychology, 46(3), 569-592.

Kaiser, F., Maassen, P., Meek, L., van Vught, F., de Weert, E., \& Goedegebuure, L. (2014). Higher education policy: An international comparative perspective. Oxford: Pergamon Press. 
Kenway, J., Bullen, E. \& Robb, S. (2004) The knowledge economy, the techno-preneur and the problematic future of the university, Policy Futures in Education, 2(2), 330-345.

Lach, S., \& Schankerman, M. (2004). Royalty Sharing and Technology Licensing in Universities. Journal of the European Economic Association, 2(2-3), 252-64.

Larédo, P. (2003). Six major challenges facing public intervention in higher education, science, technology and innovation. Science and Public Policy, 30(1), 4-12.

Link, A.N., \& Siegel, D.S. (2005). Generating Science-based Growth: An Econometric Analysis of the Impact of Organizational Incentives on University-Industry Technology Transfer', European Journal of Finance, 11(3), 169-82.

Lockett, A., \& Wright, M. (2005). Resources, capabilities, risk capital and the creation of university spin-out companies. Research policy, 34(7), 1043-1057.

Lockett, A., Wright, M., \& Franklin, S. (2003). Technology transfer and universities' spin-out strategies. Small Business Economics, 20(2), 185-200.

Maassen, P., \& Stensaker, B. (2011). The knowledge triangle, European higher education policy logics and policy implications. Higher Education, 61(6), 757-769.

Macho-Stadler, I., Martinez-Giralt, X., \& Perez-Castrillo, J. D. (1996). The role of information in licensing contract design. Research Policy, 25(1), 43-57.

Markman, G. D., Gianiodis, P. T., \& Phan, P. H. (2008). Full-time faculty or part-time entrepreneurs. IEEE transactions on engineering management, 55(1), 29-36.

Markman, G. D., Phan, P. H., Balkin, D. B., \& Gianiodis, P. T. (2005). Entrepreneurship and universitybased technology transfer. Journal of Business Venturing, 20(2), 241-263.

Marksman, G. D., Gianodis, P. T., Phan, P. H., \& Balkin, D. B. (2004). Entrepreneurship from the ivory tower: Do incentive systems matter? Journal of Technology Transfer, 29(3), 353-364.

Meister, J.C. (1998). Corporate universities: Lessons in building a world-class work force. New York: Prentice-Hill.

Micklethwait, J., \& Wooldridge, A. (1996). The witch doctors. New York: Times Books.

Mowday, R.T. (1997). Presidential Address: Reaffirming our scholarly values, Academy of Management Review, 22, 335-345.

Nonaka, I., \& Takeuchi, H. (1995). The knowledge-creating company: How Japanese companies create the dynamics of innovation. Oxford: Oxford University Press.

Ozga, J., \& Jones, R. (2006). Travelling and embedded policy: the case of knowledge transfer. Journal of education policy, 21(1), 1-17.

Paradeise, C., Reale, E., Bleiklie, I., \& Ferlie, E. (2009). University governance Western European comparative perspectives. Dordrecht: Springer.

Peters, B. G. (2001). The future of governing. Lawrence, KS: University Press of Kansas. 
Peters, M. (20019) National education policy constructions of the 'knowledge economy', Journal of Educational Enquiry, 2(1), 1-22.

Pfeffer, J., \& Sutton, R.I. (2000). The knowing-doing gap: How smart companies turn knowledge into action. Boston: Harvard Business School Press.

Powell, W. W., \& Owen-Smith, J. (1998). Universities and the market for intellectual property in the life sciences. Journal of policy analysis and management, 253-277.

Roberts, E. B., \& Malonet, D. E. (1996). Policies and structures for spinning off new companies from research and development organizations. R\&D Management, 26(1), 17-48.

Schwarz, S., \& Westerheijden, D. F. (2004). Accreditation and evaluation in the European higher education area. Dordrecht: Kluwer Academic Publishers.

Shrivastava, P., \& Mitroff, I. I. (1984). Enhancing organizational research utilization: The role of decision makers' assumptions. Academy of Management Review, 9(1), 18-26.

Siegel, D. S., \& Phan, P. H. (2005). Analyzing the effectiveness of university technology transfer: implications for entrepreneurship education. In University entrepreneurship and technology transfer (pp. 1-38). Emerald Group Publishing Limited.

Siegel, D. S., Veugelers, R., \& Wright, M. (2007). Technology transfer offices and commercialization of university intellectual property: performance and policy implications. Oxford Review of Economic Policy, 23(4), 640-660.

Siegel, D. S., Waldman, D. A., Atwater, L. E., \& Link, A. N. (2004). Toward a model of the effective transfer of scientific knowledge from academicians to practitioners: qualitative evidence from the commercialization of university technologies. Journal of Engineering and Technology Management, 21(1), 115-142.

Slaughter, S., \& Leslie, L. (1997). Academic capitalism. Baltimore: Johns Hopkins University Press.

Stensaker, B., Enders, J., \& de Boer, H. (2006). The extent and impact of higher education governance reforms across Europe, comparative analysis. Enschede: CHEPS/CHE/ESMU/NIFU STEP.

Thomas, K. W., \& Tymon, W. G. (1982). Necessary properties of relevant research: Lessons from recent criticisms of the organizational sciences. Academy of Management Review, 7(3), 345-352.

Thursby, J. G., \& Thursby, M. C. (2002). Who is selling the ivory tower? Sources of growth in university licensing. Management science, 48(1), 90-104.

Thursby, J. G., Jensen, R., \& Thursby, M. C. (2001). Objectives, characteristics and outcomes of university licensing: A survey of major US universities. The Journal of Technology Transfer, 26(12), 59-72.

Thursby, J., Fuller, A. W., \& Thursby, M. (2009). US faculty patenting: Inside and outside the university. Research Policy, 38(1), 14-25.

Valentin, F., \& Jensen, R. L. (2007). Effects on academia-industry collaboration of extending university property rights. The Journal of Technology Transfer, 32(3), 251-276. 
Van Vught, F. A. (2008). Mission diversity and reputation in higher education. Higher Education Policy, 21(2), 151-174.

World Bank (2002) Constructing knowledge societies: new challenges for tertiary education (Washington DC, World Bank).

Wright, M. (2007). Academic entrepreneurship in Europe. Edward Elgar Publishing.

Wright, M., Birley, S., \& Mosey, S. (2004). Entrepreneurship and university technology transfer. The Journal of Technology Transfer, 29(3), 235-246. 
